\title{
Beta-2-Glycoprotein 1
}

National Cancer Institute

\section{Source}

National Cancer Institute. Beta-2-Glycoprotein 1. NCI Thesaurus. Code C142155.

Beta-2-glycoprotein 1 (345 aa, $\sim 38 \mathrm{kDa}$ ) is encoded by the human APOH gene. This protein is involved in binding to phospholipids, glycosaminoglycans and other negatively charged substances. 